\title{
Effect of Combined Organic and Inorganic Fertilizer Application on Soil Attributes, Yield and Quality of Sweet Potato (Ipomoea batatas L.)*
}

\author{
Járisson Cavalcante Nunes (Corresponding author) \\ Center for Agricultural, Natural and Letters Sciences, State University of the Tocantina \\ Region of Maranhão (CCANL/UEMASUL), 65975-000, Estreito, Maranhão, Brazil. \\ *Research performed during the Post-Doctoral Internship, PNPD-Capes, Postgraduate \\ Program in Agroecology, UERR/EMBRAPA/IFRR. \\ Email: jarissonagro@hotmail.com
}

Jandiê Araújo da Silva, Marcelo Barbosa Gomes Neto, Jair Costa Bezerra

Federal University of Roraima, Campus Murupu, 69300-000, Boa Vista, Roraima, Brazil.

Juliete Araújo da Silva Nunes

Federal University of Santa Maria, 97105-900, Santa Maria, Rio Grande do Sul, Brazil.

Plínio Henrique Oliveira Gomide

Postgraduate Program in Agroecology, UERR/EMBRAPA/IFRR, 69306-530, Boa Vista, Roraima, Brazil.

Daniela Cavalcante dos Santos Campos, Dayanne Beatriz Silva Rodrigues

Federal University of Roraima, Campus Murupu, 69300-000, Boa Vista, Roraima, Brazil.

Received: June 22, 2020

Accepted: August 17, 2020

Published: August 23, 2020

doi:10.5296/jas.v8i4.17217

URL: https://doi.org/10.5296/jas.v8i4.17217

\section{Abstract}

The use of organic fertilizers in adequate doses is an alternative to reduce the use of inorganic 
inputs, improving the soil chemical attributes, and increasing the production and quality of sweet potato. In this perspective, the objectives of this study were: (i) to evaluate the effects of fertilization with poultry and bovine manure, Ribumin ${ }^{\circledR}$, and of conventional fertilization on soil attributes, production, and quality of sweet potato; and (ii) to evaluate the residual effect of organic fertilization on the production components and quality of sweet potato, in the second crop cycle. The two experiments were developed in the 2018/2019 crop year at the Agrotechnical School of the Federal University of Roraima (UFRR), Brazil. The treatments were arranged in a randomized block design with three replications, using a $(2 \times 5 \times 2)+1$ factorial arrangement referring to two manure sources (bovine and poultry manure) and five doses, aiming at increasing the content of soil organic matter $(1.35 \%)$ to $2.35 ; 3.35 ; 4.35$, and $5.35 \%$, in the absence and presence of $\operatorname{Ribumin}^{\circledR}$, and an additional treatment referring to organomineral fertilization. For the evaluation of the second cycle, the residual effect of the manure was evaluated by applying only Ribumin ${ }^{\circledR}$ and conventional fertilizers. In the first cycle, the addition of $50.4 \mathrm{t} \mathrm{ha}^{-1}$ of bovine manure without Ribumin ${ }^{\circledR}$ provided the highest values of total $\left(14.7 \mathrm{t} \mathrm{ha}^{-1}\right)$ and marketable yield $\left(14.6 \mathrm{t} \mathrm{ha}^{-1}\right)$. However, the addition of poultry manure associated with the application of Ribumin ${ }^{\circledR}$ provided no increments in the sweet potato production components. Under the same experimental conditions, chemical fertilization can be replaced by fertilization with organic sources.

Keywords: poultry manure; bovine manure; inorganic fertilizer; Ribumin ${ }^{\circledR}$; soil chemical attributes; smallholder farmers

\section{Introduction}

Sweet potato (Ipomoea batatas L.) is a horticultural species of the family Convolvulaceae, being the seventh most consumed carbohydrate-rich food source in the world (Chueyen and Eun, 2013). The world production of sweet potato in 2017 was 184,867,095 t, with China ranking as the main producer $(72,031,782 \mathrm{t})$ and Brazil $(776,285 \mathrm{t})$ occupying the tenth position in the global ranking (Faostat, 2016). The Northeast, South, and Southeast regions of Brazil are the largest national producers of sweet potato, with 251,901 t, 250,618 $\mathrm{t}$, and 214,230 t, respectively. In 2018, the state of Roraima alone produced 1,486 tons, the equivalent to $0.20 \%$ of the national production (IBGE, 2018).

The importance of this crop includes nutritional and health benefits related to the consumption of the tuberous root. According to Chueyen and Eun (2013), sweet potato possesses phenolic compounds, anthocyanins, sporamins, carotenoids (Hussein et al., 2014), vitamins $\mathrm{A}, \mathrm{B}, \mathrm{C}, \mathrm{K}$, and $\mathrm{E}$, which are important in the prevention of several diseases, contributing to food security in some regions (Low et al., 2017; Iese et al., 2018). Furthermore, sweet potato is a highly energetic food due to its high starch content, and can also be used in the biodiesel and bioethanol industry (Silva et al., 2018a). In Brazil, besides these benefits, the crop is also important for generating jobs and income for smallholder farmers.

In the state of Roraima, although sweet potato cultivation prevails in rural settlement areas, such as the Nova Amazônia Settlement Project, producers perform fertilization, in most cases, using synthetic inputs (ammonium sulfate, urea, and potassium chloride). Despite the 
potential of the crop and the availability of organic inputs (bovine and poultry manure) in the region, there still a lack of scientific data on the management of organic fertilization, contributing to rising production costs with the application of doses beyond the required by the crop and reducing the yield, profitability, and quality of harvested products (Oliveira et al., 2006; Rós et al., 2014) since nutritional imbalances, especially nitrogen excess, can compromise the formation of tuberous roots in the sweet potato crop. In this perspective, it is necessary to seek alternatives that can reduce production costs, increase the yield, and improve the soil chemical attributes.

One of the alternatives is the replacement of high-cost mineral fertilizers by plant and animal origin products that are available in the field, which, besides having more affordable prices, exert a positive influence on soil properties (Silva et al., 2016a), also featuring less aggressive environmental effects (Kuzucu, 2019; Ciaccia et al., 2019). In the last few years, new technologies available on the market, such as correctives and fertilizers, if used inefficiently, may pose environmental risks that are potentialized by anthropic action, such as groundwater contamination. From this perspective, it is essential to adopt practices that can reduce the environmental and ecological risks caused by conventional agriculture, using more intensely the natural resources in the properties and surrounding areas (Yu-Kui., 2009).

Besides these aspects, it is necessary to consider that, in the last few decades, Brazilian and global consumers are increasingly demanding products obtained from crops cultivated with less synthetic fertilizers (Kikuchi-Uehara et al., 2016; Khan and Mohsin, 2017). In this regard, agroecological production has considerably increased the use of organic fertilizers in partial and sometimes even total replacement to mineral fertilizers. Among the organic fertilizers, bovine and poultry manure and Ribumin ${ }^{\circledR}$ are highlighted (Santos et al., 2010a; Nsa et al., 2013; Silva et al., 2016b).

The use of manure in vegetable cultivation contributes positively to improve the mineral composition and productivity of agricultural crops (Mueller et al., 2013; Adeyeye et al., 2016; Singh et al., 2017), also improving the soil chemical attributes (Mantovani et al., 2017). Besides the supply of manure, the application of humic substances, such as Ribumin ${ }^{\circledR}$, can stimulate the improvement of soil attributes (Mellek et al., 2010), resulting in higher root activity, production, and quality of harvested products. However, for the proper supply of adequate sources and doses, it is essential to consider the type of crop under cultivation, the edaphoclimatic conditions of the region, and the quality of the organic material provided.

In view of this, the objectives of this study were: (i) to evaluate the effects of fertilization with poultry and bovine manure, Ribumin ${ }^{\circledR}$, and of conventional fertilization on soil attributes, production, and quality of sweet potato; (ii) to evaluate the residual effect of organic fertilization on the production components and quality of sweet potato, in the second crop cycle.

\section{Material and Methods}

The study was conducted in the Olericulture Sector of the Agrotechnical School of the Federal University of Roraima (UFRR), Campus Murupu, municipality of Boa Vista-RR 
$\left(03^{\circ} 04^{\prime} 01.3^{\prime} \mathrm{N} 60^{\circ} 48^{\prime} 45.6^{\prime \prime} \mathrm{W}\right)$. The climate of the municipality is classified as $A w$, which means rainy tropical, hot and wet (Alvares et al., 2013), presenting a well-defined rainless period (October to March) and a rainy season (April to September).

The experiment was performed in the 2018/2019 crop year, with two sweet potato cultivations: the first from June 15 to October 3, 2018 (rainy season), and the second from December 18, 2018, to April 08, 2019 (dry season). The data referring to the daily air temperature (Figure 1A, B) and precipitation (Figure 1C, D), in the periods mentioned above, were collected with an automatic weather station of the National Meteorology Institute (INMET, 2019). The mean air temperature and precipitation values in the first and second experiments were 27.4 and $29.7{ }^{\circ} \mathrm{C}$, and 1,170.4 and $16.2 \mathrm{~mm}$, respectively (Figure 1).
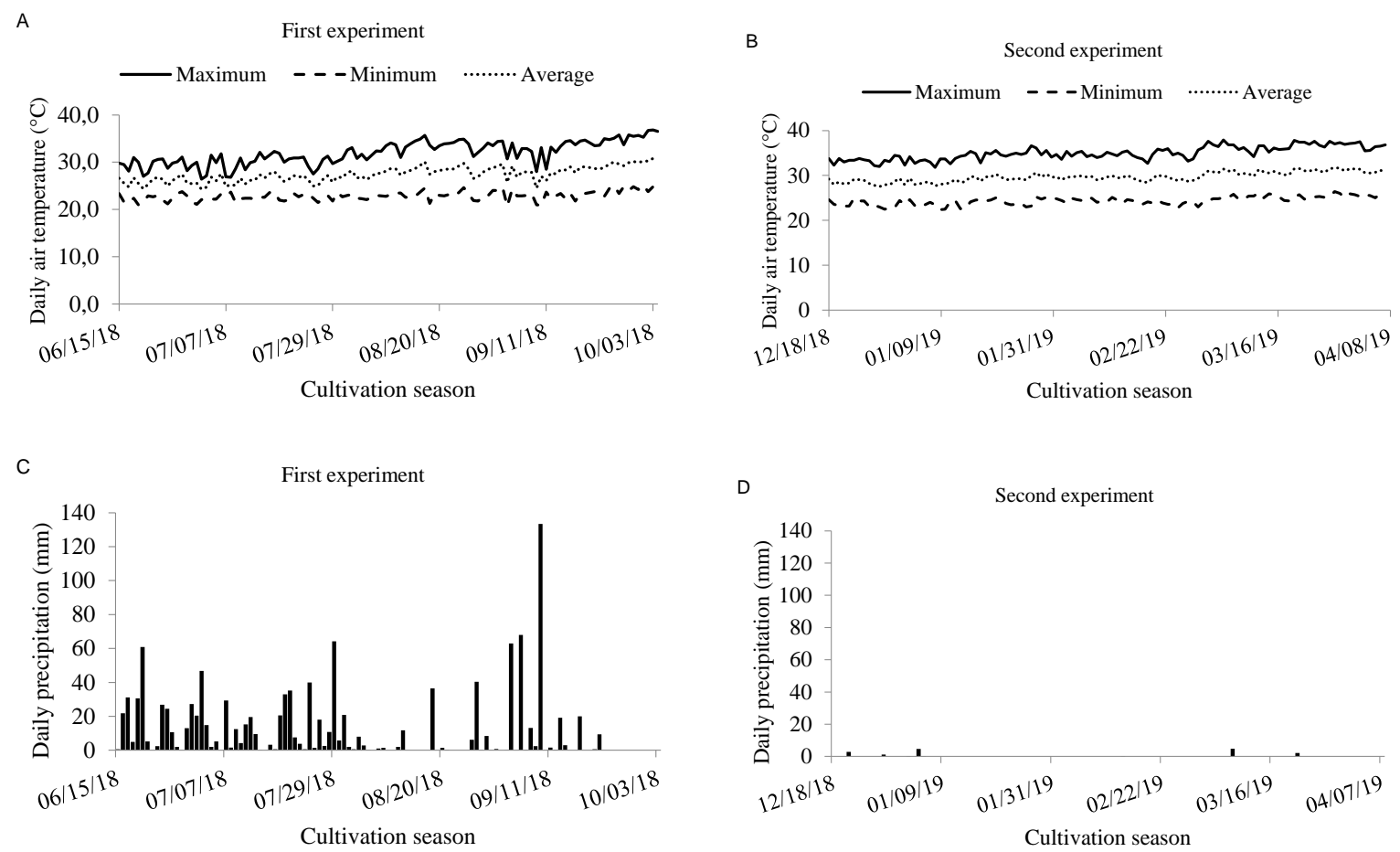

Figure 1. Daily air temperature $(A, B)$ and precipitation $(C, D)$ in the municipality of Boa Vista-RR, in the first experiment $(\mathrm{A}, \mathrm{C})$, during the rainy season, and in the second experiment $(B, D)$, during the dry season

Before the installation of the experiment, soil samples were collected at 0-20 cm depth with the aid of a Dutch auger and sent to the Laboratory of Soil Analyses of Viçosa LLC, in Viçosa-MG, for the evaluation of the chemical (Table 1) and physical attributes, following the methodology by Embrapa (2011). The $\mathrm{pH}$ was determined in a soil: liquid $\left(\mathrm{H}_{2} \mathrm{O}\right)$ suspension; the organic carbon was determined by wet oxidation of organic matter with potassium dichromate in a sulfuric medium; the cation exchange capacity and the exchangeable bases were determined by the $\mathrm{KCl} 1 \mathrm{~mol} \mathrm{~L}^{-1}$ method; the exchangeable acidity referred to the acidity released by the reaction with a non-buffered solution of $\mathrm{KCl}$, and the potential acidity was obtained by extraction with a buffered solution of calcium acetate $1 \mathrm{~mol} \mathrm{~L}^{-1} \mathrm{pH}$ 7.0. The particle size analysis was determined by the pipette method. The soil of the experimental area 
was classified as an Acrisol (WRB, 2014).

Table 1. Soil chemical attributes $(0-20 \mathrm{~cm})$ before the preparation of the planting piles in the experimental area of the Agrotechnical School of the UFRR, Campus Murupu

\begin{tabular}{cccccccccccc}
\hline $\mathrm{pH}$ & $\mathrm{P}$ & $\mathrm{K}^{+}$ & $\mathrm{S}$ & $\mathrm{Ca}^{+2}$ & $\mathrm{Mg}^{+2}$ & $\mathrm{Al}^{+3}$ & $\mathrm{H}^{+}+\mathrm{Al}^{+3}$ & $\mathrm{SB}$ & $\mathrm{CEC}$ & $\mathrm{V}$ & $\mathrm{SOM}$ \\
\hline $\mathrm{H}_{2} \mathrm{O}$ & $------m g$ & $\mathrm{dm}{ }^{-3}-------$ & $----------------------\mathrm{cmol}_{\mathrm{c}} \mathrm{dm}^{-3}----------------------$ & $--\%$-- & $\mathrm{g} \mathrm{kg}^{-1}$ \\
5.20 & 6.00 & 26.00 & 4.00 & 0.50 & 0.20 & 0 & 1.49 & 0.80 & 2.30 & 34.0 & 13.50 \\
\hline
\end{tabular}

Note. $\mathrm{SB}=$ Sum of bases $\left(\mathrm{Ca}^{2+}+\mathrm{Mg}^{2+}+\mathrm{K}^{+}+\mathrm{Na}^{+}\right)$; $\mathrm{CEC}=$ Cation Exchange Capacity $[\mathrm{SB}+$ $\left.\left(\mathrm{H}^{+}+\mathrm{Al}^{3+}\right)\right] ; \mathrm{V}=$ Saturation by exchangeable bases $(\mathrm{SB} / \mathrm{CEC}) 100 ; \mathrm{SOM}=$ Soil organic matter.

The contents of sand, silt, clay, clay dispersed in water, and soil and particle density were, respectively, $76.6 \%, 8.4 \%, 15.0 \%, 0.065 \mathrm{~kg} \mathrm{~kg}^{-1}, 1.20$, and $2.76 \mathrm{~g} \mathrm{~cm}^{-3}$, which allowed classifying the soil as of sandy-loam texture. Regarding the dry matter of the poultry and bovine manures, the following values were determined: macronutrient content, $\mathrm{C} / \mathrm{N}$ ratio, density (D), organic matter content (MO), and moisture (U), with values of $\mathrm{N}=1.94$ and $3.33 \% ; \mathrm{P}=0.22$ and $1.53 \% ; \mathrm{K}=1.68$ and $2.08 \% ; \mathrm{Ca}=0.70$ and $11.06 \% ; \mathrm{Mg}=0.32$ and $0.41 \% ; \mathrm{S}=0.25$ and $0.44 \% ; \mathrm{C} / \mathrm{N}=13.98$ and $3.41 ; \mathrm{OM}=467.8$ and $196.1\left(\mathrm{~g} \mathrm{~kg}^{-1}\right) ; \mathrm{D}=0.34$ and $0.77 \%$, and $\mathrm{U}=$ 29.36 and $5.41 \%$, respectively.

The treatments (Table 2) were arranged in randomized blocks, with three replications, in a (2 $\times 5 \times 2$ ) +1 factorial arrangement referring to two manure sources (bovine and poultry manure) and five doses, aiming at increasing the content of soil organic matter from $1.35 \%$ (Table 1 ) to $2.35 ; 3.35 ; 4.35$, and $5.35 \%$, in the absence and presence of Ribumin ${ }^{\circledR}$, and an additional treatment referring to organomineral fertilization. Ribumin ${ }^{\circledR}$ is a peat-based material with high contents of humic substances, and, according to the manufacturer, it contains $2 \%$ nitrogen, $3 \%$ potassium oxide, $5 \%$ NPK, and $3 \%$ of total organic carbon. In both experiments, the product was applied twice at the dose of $20 \mathrm{~mL} \mathrm{~L}^{-1}$, and each planting hole received $100 \mathrm{~mL}$ of the mixture in each application, at 15 and 50 days after transplantation. The experimental plot was constituted by three planting piles with $240 \mathrm{~cm}$ length, spaced $80 \mathrm{~cm}$ in the row, and $30 \mathrm{~cm}$ between plants, totaling 24 plants per plot, in which the plants of the central pile were evaluated. 
Table 2. Description of the treatments used in the experiment

\begin{tabular}{|c|c|c|c|c|c|c|c|c|}
\hline Treatments & Cicle & $\begin{array}{l}\text { Type of } \\
\text { manure }\end{array}$ & $\begin{array}{c}\% \text { of soil } \\
\text { organic } \\
\text { matter }\end{array}$ & Ribumin $^{\circledR}$ & Cicle & $\begin{array}{l}\text { Type of } \\
\text { manure }\end{array}$ & $\begin{array}{c}\% \text { of soil } \\
\text { organic } \\
\text { matter }\end{array}$ & Ribumin $^{\circledR}$ \\
\hline 1 & First & Bovine & 1.35 & Without & Second & $\begin{array}{l}\text { Residual } \\
\text { effect }\end{array}$ & $\begin{array}{c}\text { Residual } \\
\text { effect }\end{array}$ & Without \\
\hline 2 & First & Bovine & 1.35 & With & Second & $\begin{array}{l}\text { Residual } \\
\text { effect }\end{array}$ & $\begin{array}{c}\text { Residual } \\
\text { effect }\end{array}$ & With \\
\hline 3 & First & Bovine & 2.35 & Without & Second & $\begin{array}{c}\text { Residual } \\
\text { effect }\end{array}$ & $\begin{array}{c}\text { Residual } \\
\text { effect }\end{array}$ & Without \\
\hline 4 & First & Bovine & 2.35 & With & Second & $\begin{array}{l}\text { Residual } \\
\text { effect }\end{array}$ & $\begin{array}{l}\text { Residual } \\
\text { effect }\end{array}$ & With \\
\hline 5 & First & Bovine & 3.35 & Without & Second & $\begin{array}{l}\text { Residual } \\
\text { effect }\end{array}$ & $\begin{array}{c}\text { Residual } \\
\text { effect }\end{array}$ & Without \\
\hline 6 & First & Bovine & 3.35 & With & Second & $\begin{array}{l}\text { Residual } \\
\text { effect }\end{array}$ & $\begin{array}{c}\text { Residual } \\
\text { effect }\end{array}$ & With \\
\hline 7 & First & Bovine & 4.35 & Without & Second & $\begin{array}{l}\text { Residual } \\
\text { effect }\end{array}$ & $\begin{array}{l}\text { Residual } \\
\text { effect }\end{array}$ & Without \\
\hline 8 & First & Bovine & 4.35 & With & Second & $\begin{array}{l}\text { Residual } \\
\text { effect }\end{array}$ & $\begin{array}{c}\text { Residual } \\
\text { effect }\end{array}$ & With \\
\hline 9 & First & Bovine & 5.35 & Without & Second & $\begin{array}{c}\text { Residual } \\
\text { effect }\end{array}$ & $\begin{array}{c}\text { Residual } \\
\text { effect }\end{array}$ & Without \\
\hline 10 & First & Bovine & 5.35 & With & Second & $\begin{array}{c}\text { Residual } \\
\text { effect }\end{array}$ & $\begin{array}{c}\text { Residual } \\
\text { effect }\end{array}$ & With \\
\hline 11 & First & Poultry & 1.35 & Without & Second & $\begin{array}{l}\text { Residual } \\
\text { effect }\end{array}$ & $\begin{array}{c}\text { Residual } \\
\text { effect }\end{array}$ & Without \\
\hline 12 & First & Poultry & 1.35 & With & Second & $\begin{array}{c}\text { Residual } \\
\text { effect }\end{array}$ & $\begin{array}{c}\text { Residual } \\
\text { effect }\end{array}$ & With \\
\hline 13 & First & Poultry & 2.35 & Without & Second & $\begin{array}{l}\text { Residual } \\
\text { effect }\end{array}$ & $\begin{array}{l}\text { Residual } \\
\text { effect }\end{array}$ & Without \\
\hline 14 & First & Poultry & 2.35 & With & Second & $\begin{array}{l}\text { Residual } \\
\text { effect }\end{array}$ & $\begin{array}{l}\text { Residual } \\
\text { effect }\end{array}$ & With \\
\hline 15 & First & Poultry & 3.35 & Without & Second & $\begin{array}{l}\text { Residual } \\
\text { effect }\end{array}$ & $\begin{array}{l}\text { Residual } \\
\text { effect }\end{array}$ & Without \\
\hline 16 & First & Poultry & 3.35 & With & Second & $\begin{array}{l}\text { Residual } \\
\text { effect }\end{array}$ & $\begin{array}{l}\text { Residual } \\
\text { effect }\end{array}$ & With \\
\hline 17 & First & Poultry & 4.35 & Without & Second & $\begin{array}{c}\text { Residual } \\
\text { effect }\end{array}$ & $\begin{array}{l}\text { Residual } \\
\text { effect }\end{array}$ & Without \\
\hline 18 & First & Poultry & 4.35 & With & Second & $\begin{array}{l}\text { Residual } \\
\text { effect }\end{array}$ & $\begin{array}{l}\text { Residual } \\
\text { effect }\end{array}$ & With \\
\hline 19 & First & Poultry & 5.35 & Without & Second & $\begin{array}{l}\text { Residual } \\
\text { effect }\end{array}$ & $\begin{array}{l}\text { Residual } \\
\text { effect }\end{array}$ & Without \\
\hline 20 & First & Poultry & 5.35 & With & Second & $\begin{array}{l}\text { Residual } \\
\text { effect }\end{array}$ & $\begin{array}{c}\text { Residual } \\
\text { effect }\end{array}$ & With \\
\hline 21 & First & Additional & Additional & Additional & Second & Additional & Additional & Additional \\
\hline
\end{tabular}

Note. Additional: Increase of the soil organic matter content to $3.35 \%$ with the application of $12.6 \mathrm{t} \mathrm{ha}^{-1}$ of bovine manure and $24.0 \mathrm{t} \mathrm{ha}^{-1}$ of poultry manure in addition to the mineral fertilization with urea $\left(20 \mathrm{~kg} \mathrm{ha}^{-1}\right.$ of $\left.\mathrm{N}\right)$, single superphosphate $\left(250 \mathrm{~kg} \mathrm{ha}^{-1}\right.$ of $\left.\mathrm{P}_{2} \mathrm{O}_{5}\right)$, and potassium chloride $\left(110 \mathrm{~kg} \mathrm{ha}^{-1}\right.$ of $\left.\mathrm{K}_{2} \mathrm{O}\right)$.

Due to the soil $\mathrm{pH}$ value and the low content of nutrients, especially calcium and magnesium, soil correction was performed with the application of $1.7 \mathrm{t} \mathrm{ha}^{-1}$ of dolomitic limestone, 30 days before planting. The piles were raised manually using hoes. Fertilization at planting was 
performed based on the supply of the sources and doses that were pre-established in the experimental design, which was provided 20 days before planting the sweet potato crop. For the calculation of the manure doses applied in the first experiment, the equation proposed by Bertino et al. (2015) was adopted:

$$
\mathrm{M}=\frac{(\mathrm{MOD}-\mathrm{MOI}) \times \mathrm{V} \times \mathrm{Ds} \times \mathrm{U}}{\mathrm{MOE}}
$$

In which: M: Organic matter content to be applied per planting hole ( $\left.\mathrm{g} \mathrm{kg}^{-1}\right)$; MOD: Desired organic matter content $\left(\mathrm{g} \mathrm{kg}^{-1}\right)$; MOI: Existing organic matter content in the soil $\left(\mathrm{g} \mathrm{kg}^{-1}\right)$; V: volume of the hole in the pile $\left(\mathrm{cm}^{3}\right)$; Ds: Soil density $\left(\mathrm{g} \mathrm{cm}^{-3}\right)$; U: Manure moisture (\%); MOE: Organic matter content of the manure $\left(\mathrm{g} \mathrm{kg}^{-1}\right)$.

For the calculation, the volume of each planting hole in the pile was $9,000 \mathrm{~cm}^{-3}$, considering the planting hole dimensions of $30 \mathrm{~cm} \times 10 \mathrm{~cm} \times 30 \mathrm{~cm}$ (length, width, and depth, respectively), providing $0,12.6,25.2,37.8$, and $50.4 \mathrm{t} \mathrm{ha}^{-1}$ of bovine manure and $0,24.0,48.0$, 72.0 , and $96.0 \mathrm{t} \mathrm{ha}^{-1}$ of poultry manure to increase the soil organic matter content to the values defined in the experimental design, based on the attributes of each input. For the additional treatment, in both experiments, $20 \mathrm{~kg} \mathrm{ha}^{-1}$ of $\mathrm{N}$ was applied using urea as a source $(45 \% \mathrm{~N}), 250 \mathrm{~kg} \mathrm{ha}^{-1}$ of $\mathrm{P}_{2} \mathrm{O}_{5}$ using single superphosphate $\left(18 \% \mathrm{P}_{2} \mathrm{O}_{5}, 16 \% \mathrm{Ca}\right.$, and $\left.8 \% \mathrm{~S}\right)$, and $110 \mathrm{~kg} \mathrm{ha}^{-1}$ of $\mathrm{K}_{2} \mathrm{O}$ using potassium chloride $\left(60 \% \mathrm{~K}_{2} \mathrm{O}\right)$. The soil organic matter content was increased to $3.35 \%$ by applying $50 \%$ of bovine manure $\left(12.6 \mathrm{t} \mathrm{ha}^{-1}\right)$ and $50 \%$ of poultry manure $\left(24.0 \mathrm{t} \mathrm{ha}^{-1}\right)$. For the second experiment, the residual effect of the organic sources was evaluated by applying only Ribumin ${ }^{\circledR}$ and the mineral fertilizers in the additional treatment.

The collection of the vines of the sweet potato cultivar 'Brazlândia Roxa' was performed one day before transplantation, and the vines were selected containing, on average, eight internodes each. One vine was planted per planting hole, buried by the base with the aid of a small hook, at a depth of 10 to $12 \mathrm{~cm}$, in holes opened at the top of the piles.

Water was provided by sprinkler irrigation in the second experiment. The water volume applied was calculated in order to maintain soil moisture close to field capacity. During the conduction of field activities, in both experiments, heaping and weed and phytosanitary controls were performed using natural resources (garlic (Allium sativum) and onion extract (Allium cepa); neem extract (Azadirachta indica)).

Immediately before the harvest of the first experiment, soil samples were collected at $0-20 \mathrm{~cm}$ depth to evaluate the soil chemical attributes according to the previously described methodologies (Embrapa, 2011). After the first cultivation cycle, in the same experimental plots, the piles were reconstructed for the cultivation of the second sweet potato cycle, aiming at evaluating the residual effect of the sources applied. No manure was applied in the second experiment, although Ribumin ${ }^{\circledR}$ was applied following the same criteria adopted for the first experiment. The additional treatment received the contents of inorganic fertilizers predefined in the first cycle.

In both experiments, the plant material was collected at 110 days after planting the vines, and the roots were stored in type-K plastic crates, being afterward transported to the laboratory to 
assess the number of roots and the mass of marketable and non-marketable roots. Marketable roots were defined as all those with mass above $80 \mathrm{~g}$ and below $400 \mathrm{~g}$ (Embrapa, 1995). After the classification and weighing of the roots, the results obtained were estimated for $\mathrm{tha}^{-1}$. For the post-harvest evaluation of the sweet potato, in both experiments, the $\mathrm{pH}$ and soluble solids were evaluated. The $\mathrm{pH}$ was determined with the aid of a DMPH-2 Digimed potentiometer. A Hanna HI 9680 digital refractometer was used to determine of soluble solids, using two drops of the juice resulting from root maceration (Adolf Lutz Institute, 2005).

\subsection{Statistical Data Analysis}

The results were subjected to analysis of variance by the F-test; the means referring to the application of manure sources and Ribumin ${ }^{\circledR}$ were compared by the F-test, which is conclusive for two factors, and the relative doses of manure were compared by polynomial regression. The contrast was performed by comparing the factorial effect with the additional treatment, and Dunnett's test was performed to compare the additional treatment with all remaining treatments. Data processing was performed using the statistical software $\mathrm{SAS}^{\circledR}$, version $9.3\left(\mathrm{SAS}^{\circledR}, 2011\right)$.

\section{Results and Discussion}

The interaction of the type of manure $\times$ Ribumin $^{\circledR}$ application $\times$ doses exerted influence on the sweet potato production components (total and marketable yield) in the two crop cycles, besides exerting a significant effect on soil attributes at the end of the first cultivation cycle. Except for the organic matter contents, the contrast between the factorial and the additional treatment (organic and mineral fertilization) presented a significant difference for all variables studied (Table 3 ).

Table 3. Summary of the analysis of variance, by the mean square, for the total yield (PT), marketable yield (PC), soil $\mathrm{pH}$ ( $\mathrm{pH}$ - soil), and soil organic matter ( $\mathrm{SOM}$ ) cultivated with the sweet potato cultivar 'Brazlândia Roxa' in the first (June to October, 2018) and second cycles (December 2018 to April 2019) as a function of fertilization with organic and mineral sources

\begin{tabular}{|c|c|c|c|c|c|c|c|}
\hline \multirow{2}{*}{ SV } & \multirow{2}{*}{ DF } & \multicolumn{2}{|c|}{ First cycle } & \multicolumn{2}{|c|}{ Second cycle } & \multicolumn{2}{|c|}{ First cycle } \\
\hline & & PT & PC & PT & $\mathrm{PC}$ & $\mathrm{pH}$ - soil & SOM \\
\hline Block & 2 & $17.22^{\mathrm{ns}}$ & $4.46^{\mathrm{ns}}$ & $46.59^{\mathrm{ns}}$ & $48.83^{*}$ & $0.10^{*}$ & $0.007^{\mathrm{ns}}$ \\
\hline Manure (E) & 1 & $387.07^{* *}$ & $230.33^{* *}$ & $390.59^{* *}$ & $259.00^{* *}$ & $19.49^{* *}$ & $0.491^{* * *}$ \\
\hline Ribumin (R) & 1 & $9.34^{\mathrm{ns}}$ & $11.70^{\mathrm{ns}}$ & $5.479^{\mathrm{ns}}$ & $31.28^{\mathrm{ns}}$ & $0.38^{* *}$ & $0.017^{\mathrm{ns}}$ \\
\hline Doses (D) & 4 & $31.33^{*}$ & $33.87^{* *}$ & $102.50^{* *}$ & $89.51^{*}$ & $2.54^{* *}$ & $0.735^{* * *}$ \\
\hline $\mathrm{E} \times \mathrm{R}$ & 1 & $1.36^{\mathrm{ns}}$ & $4.15^{\mathrm{ns}}$ & $29.96^{\mathrm{ns}}$ & $55.60^{\mathrm{ns}}$ & $0.12^{\mathrm{ns}}$ & $0.006^{\mathrm{ns}}$ \\
\hline$E \times D$ & 4 & $61.10^{* *}$ & $54.58^{* *}$ & $39.61^{\mathrm{ns}}$ & $33.77^{\mathrm{ns}}$ & $1.63^{* *}$ & $0.167^{* *}$ \\
\hline $\mathrm{R} \times \mathrm{D}$ & 4 & $15.76^{\mathrm{ns}}$ & $14.29^{\mathrm{ns}}$ & $2.41^{\mathrm{ns}}$ & $5.06^{\mathrm{ns}}$ & $0.19^{* *}$ & $0.020^{\mathrm{ns}}$ \\
\hline $\mathrm{E} \times \mathrm{R} \times \mathrm{D}$ & 4 & $31.33^{* *}$ & $33.87^{* *}$ & $102.50^{* *}$ & $89.51^{* * *}$ & $2.54^{* *}$ & $0.735^{* * *}$ \\
\hline Factorial $\times$ Additional & 1 & $198.73^{* *}$ & $212.53^{* *}$ & 746.11 & 472.94 & $0.44^{* *}$ & $0.011^{\mathrm{ns}}$ \\
\hline Residue & 40 & 9.46 & 6.21 & 16.28 & 14.58 & 0.03 & 0.008 \\
\hline Total & 62 & & & & & & \\
\hline \multirow[t]{2}{*}{$\mathrm{CV} \%$} & & 4.18 & 4.31 & 11.37 & 14.01 & 2.62 & 7.48 \\
\hline & & \multicolumn{6}{|c|}{ Contrast estimation } \\
\hline Factorial $\times$ Additional & & $-8.34 \mathrm{t} \mathrm{ha}^{-1}$ & $-8.62 \mathrm{t} \mathrm{ha}^{-1}$ & $-16.15 \mathrm{t} \mathrm{ha}^{-}$ & $-12.86 \mathrm{t} \mathrm{ha}^{-1}$ & 0.39 & - \\
\hline
\end{tabular}


Note $. \mathrm{SV}=$ Source of variation; $\mathrm{DF}=$ Degree of freedom; $\mathrm{CV}=$ Coefficient of variation; ${ }^{\mathrm{ns}}$, ** and *: not significant and significant at 1 and $5 \%$ by the $\mathrm{F}$ test $(\mathrm{p}<0.05)$, respectively.

Contrast estimation indicated that the mean values of total and marketable yield, in the first sweet potato cycle of the factorial analysis (sources versus doses), were inferior in 8.34 and $8.62 \mathrm{t}$ compared to the additional treatment (15.29 $\mathrm{t} \mathrm{ha}^{-1}$ and $13.99 \mathrm{t} \mathrm{ha}^{-1}$, respectively). This difference was even greater in the second cycle, with values of 16.15 and $12.86 \mathrm{t} \mathrm{ha}^{-1}$, respectively. The mean soil $\mathrm{pH}$ value, in all treatments, was superior in 0.39 compared to the $\mathrm{pH}$ value of the additional treatment (Table 2).

In the first sweet potato cultivation cycle, regardless of the organic matter content added to the soil and of Ribumin ${ }^{\circledR}$ addition, the total yield was higher in the treatments fertilized with bovine manure (Figure $2 \mathrm{~A}$ and $2 \mathrm{~B}$ ). The addition of bovine manure linearly increased the total yield to the level of 2.8967 and $1.2635 \mathrm{t}$ per unitary increment in the soil organic matter content, in the treatments without (Figure 2A) and with (Figure 2B) Ribumin ${ }^{\circledR}$, with maximum estimated values of $14.7 \mathrm{tha}^{-1}$ and $12.56 \mathrm{t} \mathrm{ha}^{-1}$, respectively, at the highest dose of bovine manure $\left(50.4 \mathrm{t} \mathrm{ha}^{-1}\right)$. In the treatments with poultry manure, in the absence of Ribumin $^{\circledR}$, the increase in the soil organic matter content promoted an increase in the total yield up to the estimated value of $6.7 \mathrm{t} \mathrm{ha}^{-1}$ in the percentage of soil organic matter of $3.17 \%$ (Figure 2A). In the presence of Ribumin ${ }^{\circledR}$, the data did not adjust to any regression model tested, with a mean total yield of $4.65 \mathrm{t} \mathrm{ha}^{-1}$ (Figure $2 \mathrm{~B}$ ).
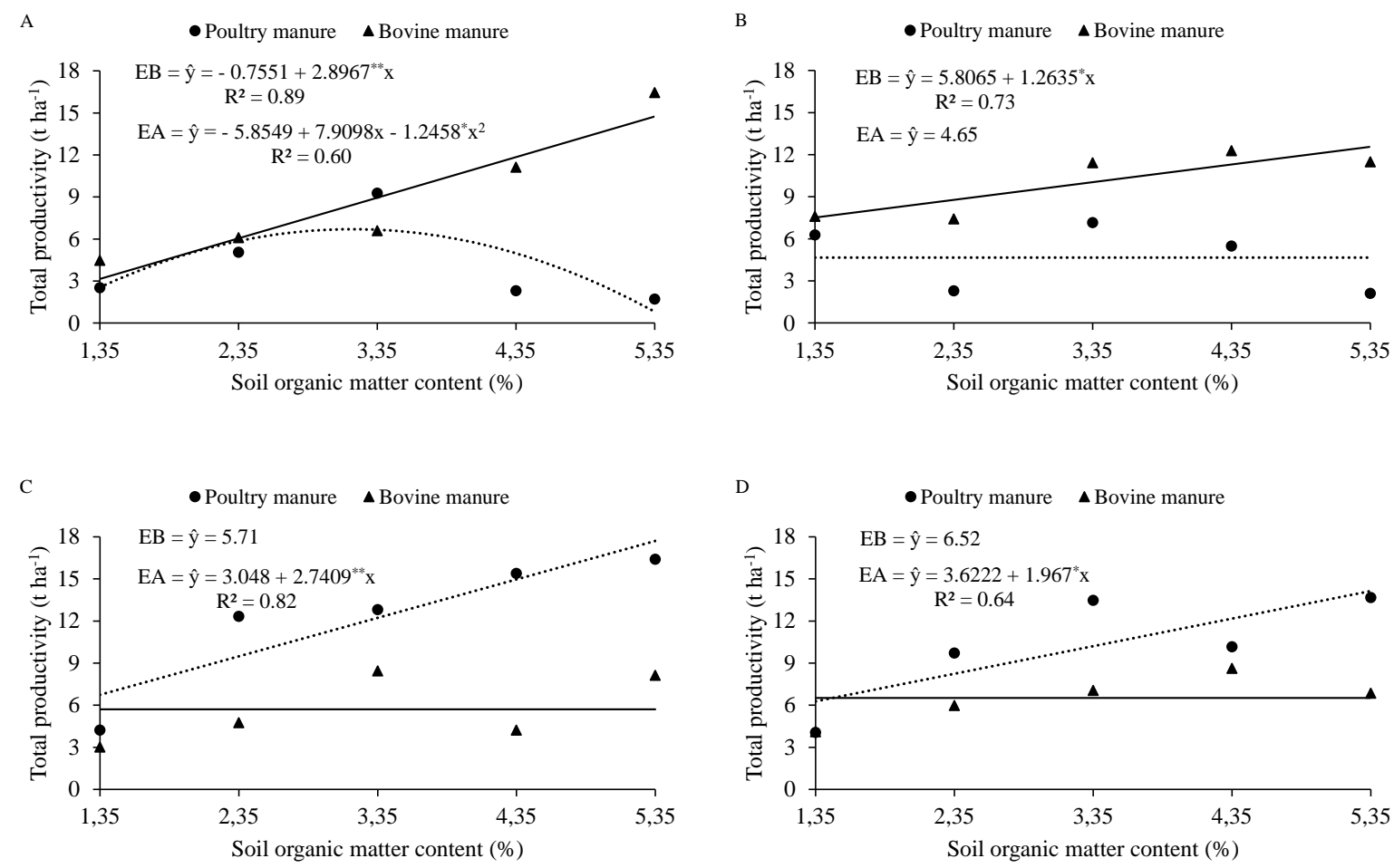

Figure 2. Total yield in the first (A, B) and second (C, D) cycle of the sweet potato cultivar 'Brazlândia Roxa' as a function of the soil organic matter content, provided through poultry (EA) and bovine manure $(\mathrm{EB})$, in the absence $(\mathrm{A}, \mathrm{C})$ and presence $(\mathrm{B}, \mathrm{D})$ of Ribumin $^{\circledR}$ 
The trend of the results was inverse in the second crop cycle, registering the highest values of total yield in the treatments fertilized with poultry manure (Figure $2 \mathrm{C}$ and 2D), regardless of the absence or presence of the organomineral fertilizer. For both situations, the data of total yield in the treatments without (Figure 2C) and with (Figure 2D) Ribumin ${ }^{\circledR}$ and fertilized with bovine manure did not adjust to the tested regression models, with mean values of 5.71 and $6.52 \mathrm{t} \mathrm{ha}^{-1}$, respectively. In the treatments without and with Ribumin ${ }^{\circledR}$, the total yield values of the treatments that received the highest dose of poultry manure were $17.7 \mathrm{t} \mathrm{ha}^{-1}$ (Figure 2C) and $14.14 \mathrm{t} \mathrm{ha}^{-1}$ (Figure 2D).

Resembling the total yield, the marketable yield of sweet potato in the first cultivation cycle, in the treatments fertilized with bovine manure, was higher with the application of the maximum dose, regardless of the absence or presence of Ribumin ${ }^{\circledR}$ (Figure 3A and 3B). When relating the marketable yield values of $3.04 \mathrm{t} \mathrm{ha}^{-1}$ and $5.75 \mathrm{t} \mathrm{ha}^{-1}$ in the treatments without the application of bovine manure, in the absence and presence of Ribumin ${ }^{\circledR}$, respectively, it was verified that the organic mineral input resulted in an $89.1 \%$ increase in the marketable yield (Figure 3A and 3B).
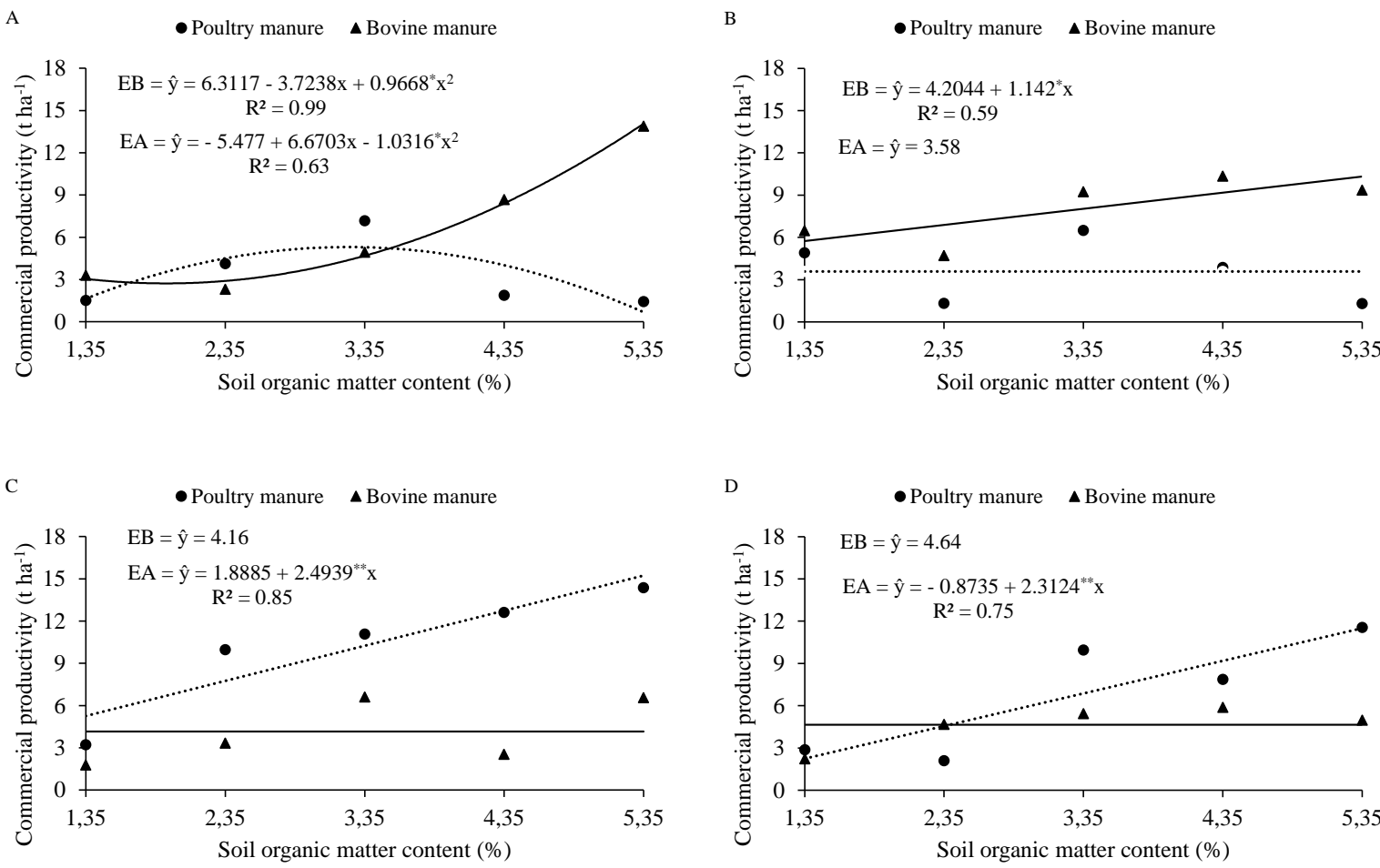

Figure 3. Marketable yield of the first (A, B) and second cycle (C, D) of the sweet potato cultivar 'Brazlândia Roxa' as a function of the soil organic matter content provided through poultry (EA) and bovine manure (EB), in the absence $(A, C)$ and presence $(B, D)$ of Ribumin $^{\circledR}$

The residual effect of the organic fertilization with poultry manure was also significant to increase the marketable yield of sweet potato in the second crop cycle. In the treatments without (Figure 3C) and with (Figure 3D) Ribumin ${ }^{\circledR}$, the maximum marketable yield values of $15.2 \mathrm{t} \mathrm{ha}^{-1}$ and $11.5 \mathrm{t} \mathrm{ha}^{-1}$ were registered with the application of the highest dose of 
poultry manure $\left(96 \mathrm{t} \mathrm{ha}^{-1}\right)$.

In the first sweet potato cultivation cycle, in the treatments with the highest dose of bovine manure, the total yield values were similar to the value registered for the national average $\left(14.5 \mathrm{t} \mathrm{ha}^{-1}\right)$. In the second cycle, fertilization with poultry manure resulted in a yield above the Brazilian average, but the values were similar to that obtained in the state of Roraima $\left(19.5 \mathrm{~kg} \mathrm{ha}^{-1}\right)$ in production systems that prioritize the use of synthetic inputs (IBGE, 2018). This situation evidences that the use of fertilization with manure is promising and might be an alternative to the replacement of fertilization with inorganic inputs (Table 5).

The higher yield values obtained in the first cycle, with the application of bovine manure, result from the chemical improvement of soil attributes (Figure 4) since the soil presented, before the installation of the experiment, low organic matter contents (Table 1). Sweet potato is considered a rustic plant, although it responds to organic fertilization (Agbede, 2010; Nicoletto et al., 2017). However, the higher nitrogen availability in the first cycle, due to the high contents of poultry manure and the application of Ribumin ${ }^{\circledR}$, may have contributed to the growth of the vegetative part of the plants to the detriment of the roots, since, in addition to the amount of input supplied to the soil having been higher, the poultry manure had a higher nitrogen content (3.33\%) and a lower $\mathrm{C} / \mathrm{N}$ ratio (3.41) compared to the bovine manure (Table 1). These attributes justify the values obtained in Figure 2 and express the cultivation potential of the sweet potato crop in a production system that prioritizes the maximum use of the existing resources in the property (Table 5).

Adeyeye et al. (2016), studying the application of $10 \mathrm{t} \mathrm{ha}^{-1}$ of three organic fertilizers (poultry manure, bovine manure, and organic compost) and fertilization with synthetic fertilizers on the production components of sweet potato, in Nigeria, verified that there was no difference between the application of inorganic and organic fertilizers on sweet potato yield. However, the highest yield value $\left(4.0 \mathrm{tha}^{-1}\right)$ was registered for the plants fertilized with urea, followed by the treatments with poultry manure, organic compost, and bovine manure, although this yield value is still below the maximum values obtained in the present study. Silva et al. (2018b), studying the intercropping of sweet potato with rattlepod and the application of poultry manure $\left(20 \mathrm{t} \mathrm{ha}^{-1}\right)$, registered a yield $16 \mathrm{tha}^{-1}$, a similar value to that obtained in the first and second cycles (Figure 2, Table 5).

Except for the treatments fertilized with bovine manure, at the end of the first cycle, the soil $\mathrm{pH}$ was increased with the supply of manures, regardless of the absence (Figure 4A) or presence (Figure 4B) of the peat-based input. In the treatments without Ribumin ${ }^{\circledR}$, the increase in soil $\mathrm{pH}$ was equivalent to $31.5 \%$ when comparing the values of the treatment that did not receive poultry manure (5.97) with the treatment that received the highest dose (7.81) of poultry input (Figure 4A). In the absence of Ribumin ${ }^{\circledR}$ (Figure 4B), although the two manure sources contributed to the increase of soil $\mathrm{pH}$, the values were superior with the application of poultry manure (7.6), compared to bovine manure (6.3). 

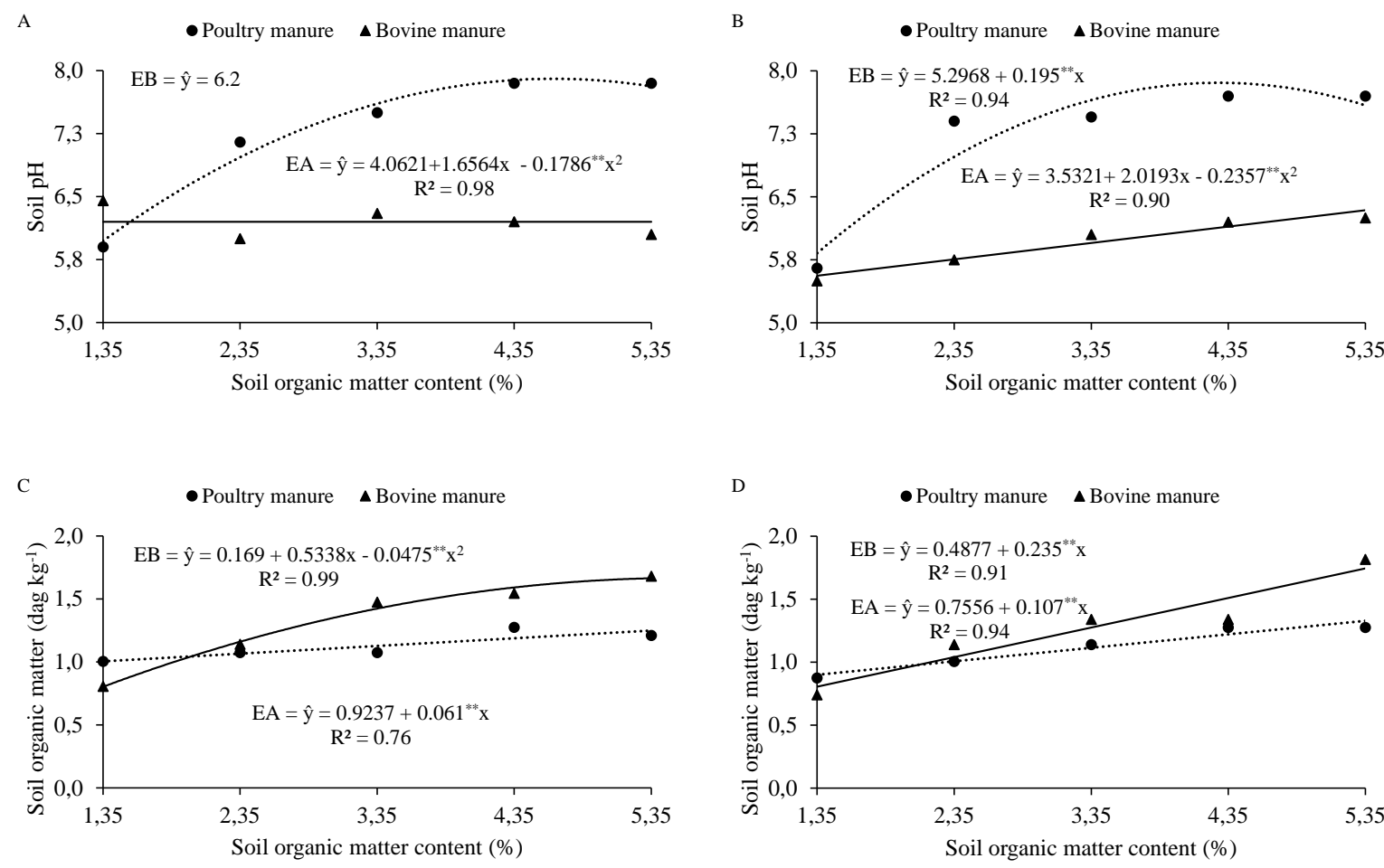

Figure 4. Soil $\mathrm{pH}(\mathrm{A}, \mathrm{B})$ and organic matter $(\mathrm{C}, \mathrm{D})$ at the end of the first cultivation cycle of the sweet potato cultivar 'Brazlândia Roxa' as a function of the content of soil organic matter provided with poultry (EA) and bovine manure $(\mathrm{EB})$, in the absence $(\mathrm{A}, \mathrm{C})$ and presence $(\mathrm{B}$, D) of Ribumin ${ }^{\circledR}$

When evaluating the content of soil organic matter at the end of the first experiment (Figure 4C and 4D), it was verified that the values obtained in all treatments were below those defined in the experimental design. However, the application of the manure doses contributed to the increase of the soil organic matter contents in the treatments without (Figure 4C) and with (Figure 4D) Ribumin ${ }^{\circledR}$, with superiority in the treatments that received the peat-based input.

When relating the values of $1.74 \mathrm{dag} \mathrm{kg}^{-1}$ and $1.66 \mathrm{dag} \mathrm{kg}^{-1}$ of the treatments that received the highest dose of bovine manure with and without Ribumin ${ }^{\circledR}$, respectively, it was verified that the organic mineral input increased promoted a $4.8 \%$ in the soil organic matter content. When relating the values of the treatments with poultry manure, it was verified that the superiority reached $6.4 \%$.

When considering: (i) the dynamics of organic matter in tropical and subtropical soils, in which the carbon fraction lost in the system may reach $10 \%\left(0.10\right.$ year $\left.^{-1}\right)$; (ii) that this rate can be influenced by climatic conditions (Figure 1) (Silva et al., 2008); and (iii) the amounts of manure added to the soil in the installation of the experiment, most of the inputs were possibly mineralized and used by the plants or lost to the system, after the first cultivation cycle (Figure 4C and 4D). The results, however, evidence the importance of organic fertilization on soil attributes (Figure 4), including the increase in $\mathrm{pH}$ (Figure 4A and 4B), which may have occurred due to the reduction in $\mathrm{H}^{+}$activity, the mineralization of organic 


\section{Macrothink

forms of nitrogen, and the denitrification and decarboxylation of organic acids (Silva et al., 2008). The supply of $100 \%$ of the manure doses, in the first cycle, contributed to the stimulation of the microbial population and, consequently, given the nutritional demand by the decomposing microbiota, mineral nutrients, such as $\mathrm{NO}_{3}{ }^{-}$, became immobilized by the new biomass. In the second cycle, due to the time factor, there was an increase in the mineralization of the material as a consequence of the reduction in microbial activity, with an increase in nutrient availability in the soil and an in the contents of soil organic matter (Figure 4), contributing to the retention of water and cations in the system by organic binders and improving the quality of the soil (Moreira and Siqueira, 2006).

Due to the greater addition of poultry manure, the positive effects of fertilization with this input were also better expressed in the second cycle, revealing the residual effect of the organic fertilization with poultry manure. According to Santos et al. (2010b), the residual effects of organic fertilization are usually better expressed in the second year of cultivation and in association with Ribumin ${ }^{\circledR}$, which works as a soil conditioning, promoting the increase of production components (Silva et al., 2016b).

The summary of the analysis of variance for the post-harvest variables of sweet potato indicates that for the two cycles studied, both for the $\mathrm{pH}$ of the pulp and soluble solids, there was a significant effect of the interaction between the type of manure $\times$ doses $\times$ Ribumin $^{\circledR}$ (Table 3). For the variables of the first cycle, it is verified that the contrast between the factorial and the additional treatment was only significant for the soluble solids of the pulp, in which the mean of the factorial $\left(7.34{ }^{\circ}\right.$ Brix) was $0.85{ }^{\circ}$ Brix inferior in relation to the additional treatment. In the second cycle, there was a significant effect for both variables analyzed; however, the $\mathrm{pH}$ (6.55) and soluble solids (6.60 ${ }^{\circ}$ Brix) of the sweet potato pulp of the factorial analysis were superior in 0.12 and $1.14{ }^{\circ}$ Brix, respectively (Table 4). 
Table 4. Summary of the analysis of variance for the $\mathrm{pH}$ and soluble solids of the pulp in the sweet potato cultivar 'Brazlândia Roxa', in the first (June to October 2018) and second cycles (December 2018 to April 2019), as a function of fertilization with organic and mineral sources

\begin{tabular}{|c|c|c|c|c|c|}
\hline \multirow{2}{*}{ SV } & \multirow{2}{*}{$\mathrm{DF}$} & \multicolumn{2}{|c|}{ First cycle } & \multicolumn{2}{|c|}{ Second cycle } \\
\hline & & $\mathrm{pH}-1$ & SS-1 & $\mathrm{pH}-2$ & SS-2 \\
\hline Block & 2 & $0.04004^{\mathrm{ns}}$ & $0.334^{\mathrm{ns}}$ & $0.003^{\mathrm{ns}}$ & $0.167^{\mathrm{ns}}$ \\
\hline Manure (E) & 1 & $0.60000^{* *}$ & $17.604^{* *}$ & $0.382^{* *}$ & $6.468^{* *}$ \\
\hline Ribumin (R) & 1 & $0.00112^{\mathrm{ns}}$ & $0.073^{\text {ns }}$ & $0.022^{*}$ & $0.840^{*}$ \\
\hline Doses (D) & 4 & $0.101405^{* *}$ & $0.736^{* *}$ & $0.024^{* *}$ & $3.416^{* *}$ \\
\hline$E \times R$ & 1 & $0.00002^{\mathrm{ns}}$ & $0.104^{\mathrm{ns}}$ & $0.002^{\mathrm{ns}}$ & $0.204^{\mathrm{ns}}$ \\
\hline $\mathrm{E} \times \mathrm{D}$ & 4 & $0.20374^{* *}$ & $0.368^{\mathrm{ns}}$ & $0.031^{* *}$ & $1.783^{* *}$ \\
\hline $\mathrm{R} \times \mathrm{D}$ & 4 & $0.01803^{\mathrm{ns}}$ & $0.287^{\mathrm{ns}}$ & $0.006^{\mathrm{ns}}$ & $0.568^{* *}$ \\
\hline $\mathrm{E} \times \mathrm{R} \times \mathrm{D}$ & 4 & $0.10140^{* *}$ & $0.736^{* *}$ & $0.024^{* *}$ & $3.416^{* *}$ \\
\hline Factorial $\times$ additional & 1 & $0.04903^{\mathrm{ns}}$ & $2.088^{* *}$ & $0.044^{*}$ & $3.724^{* *}$ \\
\hline Residue & 40 & 0.016 & 0.160 & 0.004 & 0.125 \\
\hline Total & 62 & & & & \\
\hline \multirow[t]{2}{*}{$\mathrm{CV} \%$} & & 2.24 & 5.42 & 0.99 & 5.39 \\
\hline & \multicolumn{5}{|c|}{ Contrast estimation } \\
\hline Factorial $\times$ Additional & & - & $-0.855^{\circ}$ Brix & 0.12 & 1.14 \\
\hline
\end{tabular}

Note. $\mathrm{SV}=$ Source of variation; $\mathrm{DF}=$ Degree of freedom; $\mathrm{pH}-1=\mathrm{pulp} \mathrm{pH}$ in the first cycle; SS-1= soluble solids of the pulp in the first cycle; $\mathrm{pH}-2=$ pulp $\mathrm{pH}$ in the second cycle; SS-1 $=$ soluble solids of the pulp in the second cycle; $\mathrm{CV}=$ Coefficient of variation; $\mathrm{ns}, * *$ and *: not significant and significant at 1 and $5 \%$ by the $F$ test $(\mathrm{p}<0.05)$, respectively.

Despite the significant effect of the triple interaction, in this first cycle, the data referring to the pulp $\mathrm{pH}$ in the treatments that received bovine manure did not adjust to any regression model tested, with a mean value of 5.6 in the treatments without Ribumin ${ }^{\circledR}$ (Figure 5A) and 5.7 in the treatments with Ribumin ${ }^{\circledR}$ (Figure 5B). Regardless of the application of this input, the supply of poultry manure to the soil reduced the pulp $\mathrm{pH}$ of sweet potato, with the highest 
values of 6.10 (Figure 5A) and 6.34 (Figure 5B).
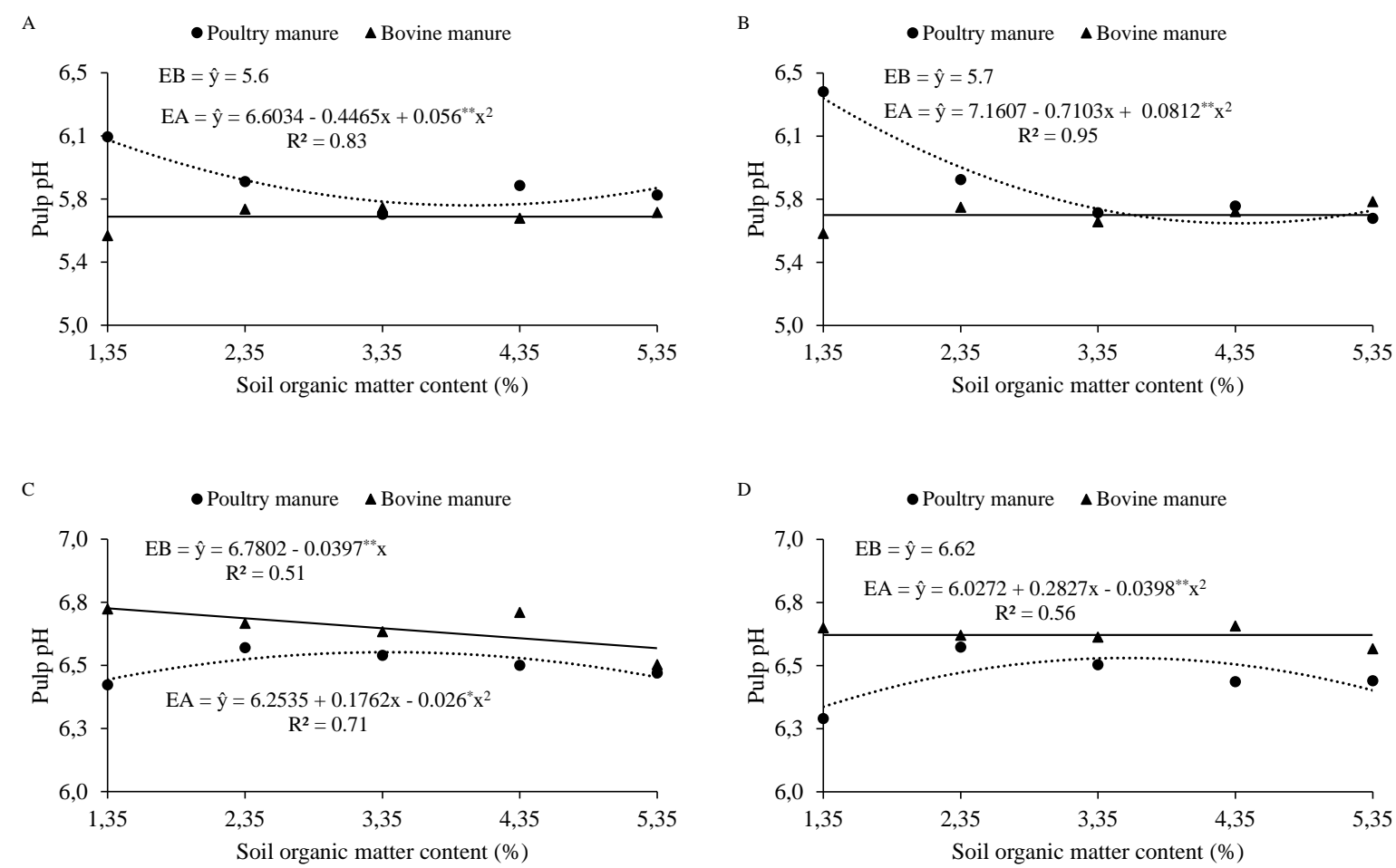

Figure 5. Pulp pH of the first (A, B) and second cultivation cycles (C, D) of the sweet potato cultivar 'Brazlândia Roxa' as a function of the content of soil organic matter provided through poultry (EA) and bovine manure $(\mathrm{EB})$, in the absence $(\mathrm{A}, \mathrm{C})$ and presence $(\mathrm{B}, \mathrm{D})$ of Ribumin $^{\circledR}$

In the second cycle, the values of pulp $\mathrm{pH}$ in the treatments with poultry manure, unlike the first cycle, were increased with the application of the poultry input, reaching maximum values of 6.5 with soil organic matter contents of $3.38 \%$ (Figure 5C) and 3.55\% (Figure 5D). The application of bovine manure in the treatments without Ribumin ${ }^{\circledR}$ reduced the $\mathrm{pH}$ of the sweet potato pulp from 6.73 to 6.56 from the lowest to the highest dose (Figure 5C), and in the presence of the organomineral input, the mean value obtained was 6.62 (Figure 5D).

The reduction of the pulp $\mathrm{pH}$ in sweet potato, in the treatments fertilized with poultry manure, in the first cycle, and in the treatments fertilized with bovine manure, without the application of Ribumin ${ }^{\circledR}$ (Figure 5), indicates that the addition of manure to the soil can favor the production of sweet potato with a slightly acid pulp, although the values are still within the range considered adequate for the crop (Uchôa et al., 2015). Pulp pH is an important attribute in sweet potato since acid values lead to losses in color intensity and in the activity of provitamin A. Marques et al. (2010) verified that the application of bovine manure to the soil does not affect the $\mathrm{pH}$ in beetroot (Beta vulgaris esculenta). The pulp $\mathrm{pH}$ results of sweet potato obtained in this research are within the range from 5.04 to 7.26 registered by Ali et al. (2015), when evaluating the physical-chemical characterization of two sweet potato cultivars (Adu and Barkume), in Ethiopia. 
The supply of Ribumin ${ }^{\circledR}$, associated with manure application, in both cycles, reduced the values of soluble solids in the sweet potato pulp (Figure 6B and 6D), although the values were superior to the first cycle, with values of soluble solids in the treatments without manure equivalent to 8.20 and $7.15^{\circ}$ Brix (Figure 6B). In the treatments without Ribumin ${ }^{\circledR}$, the mean values obtained in the first cycle were 6.88 and $7.88^{\circ} \mathrm{Brix}$, in the treatments with bovine and poultry manure, respectively (Figure 6A). For the second cycle, the mean value of soluble solids obtained for the sweet potato pulp grown in the soil fertilized with bovine manure was $7.11^{\circ}$ Brix, and the application of poultry manure also reduced the soluble solids (Figure 6C).
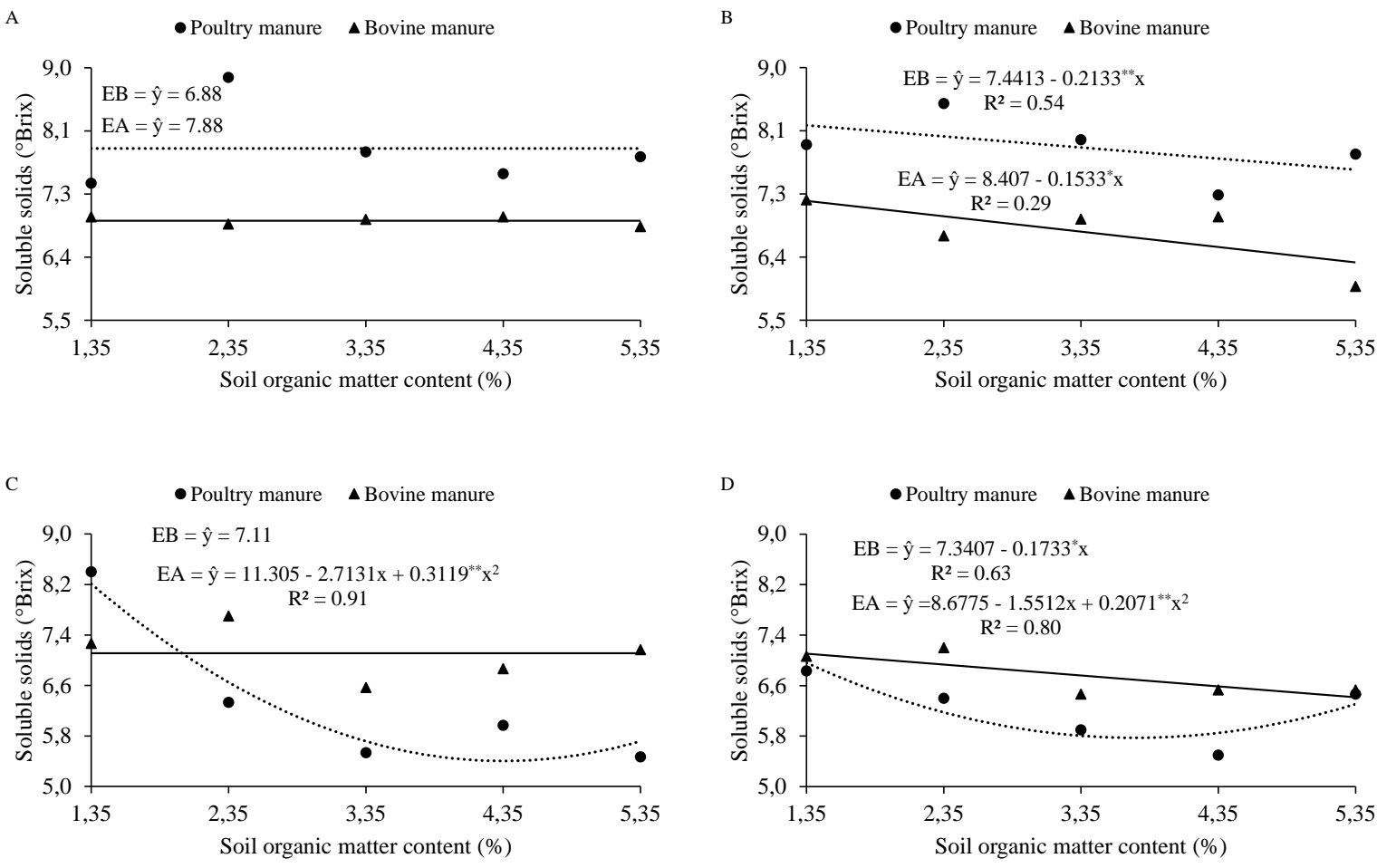

Figure 6. Soluble solids in the pulp of the sweet potato cultivar 'Brazlândia Roxa', in the first $(A, B)$ and second cycles (C, D), as a function of the initial content of soil organic matter provided through poultry (EA) and bovine manure $(\mathrm{EB}$,$) , in the absence (\mathrm{A}, \mathrm{C})$ and presence $(\mathrm{B}, \mathrm{D})$ of Ribumin ${ }^{\circledR}$

The soluble solids indirectly represent the content of sugars and organic substances, such as acids and tannins, in a specific sweet potato sample, determining the degree of sweetness of the vegetable. This quality attribute can be a determining factor for the consumer to purchase the product again with a smallholder farmer. Despite the reduction of soluble solids in the sweet potato pulp with the addition of manure, in both cycles (Figure 6), the mean values are within the range from 6.43 and $11.25^{\circ}$ Brix registered by Panja et al. (2016), when studying eight sweet potato cultivars for two years in India, although being below the mean value of $12.63{ }^{\circ}$ Brix obtained by Ali et al. (2015) when studying the physicochemical characterization of two sweet potato cultivars in Ethiopia.

Table 5 presents, for all treatments, the mean values of each variable analyzed in both cycles and the significance level of Dunnett's test. In the first cycle, in treatments 6, 7, 8, 9, and 10, 
with bovine manure, there were higher values of total and marketable yield, not differing statistically from the additional treatment, using organic and synthetic fertilizers. Treatment 9 (50.4 $\mathrm{t} \mathrm{ha}^{-1}$ of bovine manure without Ribumin ${ }^{\circledR}$ application) registered a numerically higher total yield (16.45 $\mathrm{t} \mathrm{ha}^{-1}$ ) compared to the additional treatment (15.29), and, in these same treatments, the marketable yield $\left(13.89 \mathrm{t} \mathrm{ha}^{-1}\right)$ was similar to that of treatment $21(13.99 \mathrm{t}$ $\left.\mathrm{ha}^{-1}\right)$.

Table 5. Mean values of total yield (PT1), marketable yield (PC1), soil pH (pH-soil), soil organic matter (SOM), pulp pH (pH-1), and soluble solids (SS-1) in the first cycle (June to October 2018), and total yield (PT2), marketable yield (PC2), pulp pH (pH-2), and soluble solids (SS-2) in the second cycle (December 2018 to April 2019) of the sweet potato cultivar 'Brazlândia Roxa' as a function of fertilization with organic and mineral sources

\begin{tabular}{|c|c|c|c|c|c|c|c|c|c|c|c|c|c|}
\hline \multicolumn{4}{|c|}{ Treatments } & \multicolumn{6}{|c|}{ First cycle } & \multicolumn{4}{|c|}{ Second cycle } \\
\hline \multirow[b]{2}{*}{$\mathrm{T}$} & \multirow[b]{2}{*}{$\mathrm{E}$} & \multirow{2}{*}{ SOM } & \multirow{2}{*}{$\mathrm{R}$} & 1 & PC1 & $\mathrm{H}_{-\mathrm{S}}$ & SOM & H - & SS1 & T2 & $\mathrm{PC} 2$ & pHp2 & SS2 \\
\hline & & & & \multicolumn{2}{|c|}{----t ha-1---- } & \multicolumn{3}{|c|}{$\mathrm{dag} \mathrm{kg}^{-1}$} & ${ }^{\circ} \mathrm{Bri}$ & \multicolumn{2}{|c|}{----t ha-1---- } & & ${ }^{\circ} \mathrm{Bri}$ \\
\hline 1 & Bovine & 1.35 & ithout & $4.48^{*}$ & $3.3^{*}$ & $6.45^{\text {ns }}$ & $0.81^{*}$ & $5.53^{\text {ns }}$ & $6.93^{*}$ & $3.02^{* *}$ & $1.78^{* *}$ & 6.7 & $7.27^{*}$ \\
\hline 2 & Bovine & 1.35 & & $60^{*}$ & $6.48^{*}$ & & 7 7* & $5^{\text {ns }}$ & $7.17^{*}$ & & & $6.65^{*}$ & $7.07^{*}$ \\
\hline 3 & Bovine & 35 & Witho & 6.1 & & 00 & $14^{\mathrm{ns}}$ & $69^{\text {ns }}$ & & & & $6.67^{*}$ & $7.7^{*}$ \\
\hline 4 & Bovil & 2.3 & & & 4.7 & & & & & & & & $7.2^{*}$ \\
\hline 5 & 30 & 3.35 & t & & 4.9 & & & & 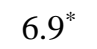 & & & & 1 \\
\hline 6 & 30 & 3.35 & & & 9.2 & 0.6 & & ns & & & & & \\
\hline 7 & $50 \mathrm{~V}$ & 4.3 & Witho & $.12^{\mathrm{ns}}$ & 8.6 & 6.2 & $1.55^{*}$ & ns & 6.9 & 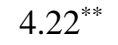 & & $1^{*}$ & 6.8 \\
\hline 8 & Bovine & 4.3 & Witl & $.28^{\mathrm{ns}}$ & $10.36^{\mathrm{ns}}$ & 0.2 & & $5.68^{\text {ns }}$ & $6.93^{*}$ & & & $66^{*}$ & $6.53^{*}$ \\
\hline 9 & & 5 & & & & & & & & & & & $7.17^{*}$ \\
\hline 10 & & 5 & & & & & & & & & & & \\
\hline 11 & $y$ & 1 & & & & & & & & & & & \\
\hline & $y$ & 1.35 & & & 4. & & & $6.39^{*}$ & 7.9 & & & $y^{\text {ns }}$ & 6. \\
\hline 13 & y & 2.35 & Witl & & 4.1 & 1. & $1.08^{\mathrm{ns}}$ & $5.85^{\mathrm{ns}}$ & $8.87^{\mathrm{ns}}$ & $12.33^{* *}$ & $9.96^{\mathrm{ns}}$ & $6.57^{\mathrm{ns}}$ & $6.33^{\text {ns }}$ \\
\hline 14 & Poultry & 2.35 & & & 1.3 & & $01^{*}$ & $5.87^{\text {ns }}$ & 8.5 & $9.71^{* *}$ & $2.10^{* *}$ & $6.57^{\mathrm{ns}}$ & $6.4^{*}$ \\
\hline 15 & ult & 3.35 & $m$ & 27. & 7.1 & & ns & $5.66^{\mathrm{ns}}$ & 7.8 & $1^{\text {*** }}$ & $11.07^{\mathrm{ns}}$ & $54^{\mathrm{ns}}$ & $5.53^{\mathrm{ns}}$ \\
\hline 16 & ultry & 3 & & & 6.4 & & & $5.67^{\text {ns }}$ & $8.00^{\text {ns }}$ & & & ns & \\
\hline 17 & bultry & 4.3 & Withe & & & & & & 7.5 & & & & 5.9 \\
\hline & $y$ & 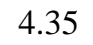 & & & & & & & & & & & \\
\hline & & 5 & & & & & & & 7.7 & & & & 5 \\
\hline & & & & & & & & & 7. & & & $14^{\text {ns }}$ & $6.47^{*}$ \\
\hline 21 & A & $\mathrm{AD}$ & A & 1. & 13.99 & 6.25 & 1.28 & 5.62 & 8.2 & 24.83 & 19.35 & 6.43 & 5.47 \\
\hline
\end{tabular}

Note $. \mathrm{T}=$ Treatment $; \mathrm{E}=$ Manure, $\mathrm{SOM}=$ Soil organic matter; $\mathrm{R}=$ Ribumin; ${ }^{\mathrm{ns}}$ and ${ }^{*}$, express non-significance and significance, respectively, by Dunnett's test at $5 \%$ of probability for comparisons with the additional treatment (21) (AD - Additional treatment).

Except for treatment 11 (without the application of poultry manure and absence of Ribumin ${ }^{\circledR}$ ), all soil $\mathrm{pH}$ values in the treatments fertilized with poultry manure (12 to 20) were superior to the value registered for the additional treatment (6.25). Regardless of the presence (1.82 dag $\mathrm{kg}^{-1}$ ) or absence $\left(1.68 \mathrm{dag} \mathrm{kg}^{-1}\right)$ of Ribumin ${ }^{\circledR}$, the supply of $50.4 \mathrm{t} \mathrm{ha}^{-1}$ of bovine manure provided soil organic matter values above those of treatment $21\left(1.28 \mathrm{dag} \mathrm{kg}^{-1}\right)$. Treatments 11 and 12 (without poultry manure) registered high pulp $\mathrm{pH}$ values in the first cycle compared to the additional treatment (5.62). All values of soluble solids in the sweet potato pulp, obtained in the first cultivation with bovine manure, were inferior to the additional treatment $\left(8.2^{\circ}\right.$ Brix $)$. 
The highest values of total $\left(24.83 \mathrm{tha}^{-1}\right)$ and marketable yield $\left(19.35 \mathrm{t} \mathrm{ha}^{-1}\right)$ were registered in the second cycle, with the additional treatment. Only treatments $17\left(15.39 \mathrm{t} \mathrm{ha}^{-1}\right)$ and 19 (16.4 $\left.\mathrm{t} \mathrm{ha}^{-1}\right)$, for the total yield, and treatments $16,17,19$, and 20 , for the marketable yield, were statistically equal to the additional treatment, and all were treated with poultry manure. The treatments that received the highest doses of bovine manure (9 and 10) and all those that received poultry manure presented a similar pulp pH to that registered for treatment 21 (6.43). All treatments fertilized with bovine manure presented contents of soluble solids in the sweet potato pulp above the mean value of the treatment with organic and mineral fertilization (5.47 ${ }^{\circ}$ Brix), as well as treatments 11 (8.40 ${ }^{\circ}$ Brix $), 12$ (6.83 $\left.{ }^{\circ} \mathrm{Brix}\right), 14$ (6.40 $\left.{ }^{\circ} \mathrm{Brix}\right)$, and 20 $\left(6.47^{\circ}\right.$ Brix), which received poultry input (Table 5).

These results indicate the possibility of smallholder farmers in the Nova Amazônia Settlement Project in practicing more sustainable agriculture using the existing resources in their community, reducing or eliminating the dependence on inorganic inputs, reducing the deleterious effects to the environment, with a sweet potato production of higher quality and added value, without yield losses, and increasing the income and quality of life of sweet potato producers in the state of Roraima.

\section{Conclusions}

In the first cycle, the addition of $50.4 \mathrm{t} \mathrm{ha}^{-1}$ of bovine manure, without the application of Ribumin $^{\circledR}$, provided the highest values of total $\left(14.7 \mathrm{t} \mathrm{ha}^{-1}\right)$ and marketable yield $\left(14.6 \mathrm{t} \mathrm{ha}^{-1}\right)$. In the cultivation during the rainy period, the addition of poultry manure associated with the application of Ribumin ${ }^{\circledR}$ provided no increments in the production components of sweet potato; however, in the second cycle, the residual effect of fertilization increased the yield of Ipomoea batatas L. The application of organic inputs improved the soil chemical attributes and provided a sweet potato production with adequate quality for the consuming Brazilian market. Under the same experimental conditions, chemical fertilization can be replaced by fertilization with organic sources.

\section{Acknowledgments}

The authors thank the à Coordination for the Improvement of Higher Education Personnel (Capes) for the concession of the Post-Doctorate scholarship (process number: 88882.315287/2019-01), and the Agrotechnical Scholl of the UFRR, for all the infrastructure provided.

\section{References}

Adeyeye, A. S., Akanbi, W. B., Sobola, O. O., Lamidi, W. A., \& Olalekan, K. K. (2016). Comparative effect of organic and in-organic fertilizer treatment on the growth and tuberyeild of sweet potato (Ipomoea batata L). International Journal of Sustainable Agricultural Research, 3(3), 54-57. https://doi.org/10.18488/journal.70/2016.3.3/70.3.54.57

Agbede, T. M. (2010). Tillage and fertilizer effects on some soil properties, leaf nutriente concentrations, growth and sweet potato yield on an Alfisol in southwestern Nigeria. Soil and Tillage Research, 110(1), 25-32. https://doi.org/10.1016/j.still.2010.06.003 
Ali, S., Mohammed, W., \& Shimelis, B. (2015). Agronomic and physicochemical evaluation of sweet potato [Ipomoea batatas (L.) Lam.] collections in Ethiopia. Advances in Crop Science and Technology, 3(3), 2-8. https://doi.org/10.4172/2329-8863.1000172

Alvares, C. A., Stape, J. L., Sentelhas, P. C., Gonçalves, J. L. M., \& Sparovek, G. (2013). Köppen's climate classification map for Brazil. Meteorologische Zeitschrift, 22(6), 711-728. https://doi.org/10.1127/0941-2948/2013/0507

Bertino, A. M. P., Mesquita, E. F., Sá, F. V. S., Cavalcante, L. F., Ferreira, N. M., Paiva, E. P., Brito, M. E. B., \& Bertino, A. M. (2015). Growth and gas exchange of okra under irrigation, organic fertilization and cover of soil. African Journal of Agricultural Research, 10(40), 3832-3839. https://doi.org/10.5897/AJAR2015.9844

Chueyen, V. H., \& Eun, J. B. (2013). Nutritional quality of foods: sweet potato. In V. R Preedy, L-A Hunter, \& V. B. Patel (Eds.), Diet Quality: An Evidence-based Approach (pp. 247-256). New York: Springer Science Business Media. https://doi.org/10.1007/978-1-4614-7339-8

Ciaccia, C., Ceglie, F. G., Burgio, G., Madžarić, S., Testani, E., Muzzi, E., Mimiola, G., \& Tittarelli, F. (2019). Impact of agroecological practices on greenhouse vegetable production: comparison among organic production systems. Agronomy, 9(7), 1-16. https://doi.org/10.3390/agronomy 9070372

Embrapa (1995). Cultivo da batata-doce (Ipomoea batatas (L.) Lam). [Online] Available: https://www.embrapa.br/busca-de-publicacoes/-/publicacao/753382/cultivo-da-batata-doce-ip omoea-batatas-1-lam (June 19, 2020).

Embrapa (2011). Manual de métodos de análise do solo. [Online] Available: https://www.embrapa.br/busca-de-publicacoes/-/publicacao/990374/manual-de-metodos-de-a nalise-de-solo (June 19, 2020).

Eyheraguibel, B., Silvestre, J., \& Morard, P. (2008). Effects of humic substances derived from organic waste enhancement on the growth and mineral nutrition of maize. Bioresource Technology, 99(10), 4202-4212. https://doi.org/10.1016/j.biortech.2007.08.082

Faostat (2017). Food and Agriculture Organization of the United Nations, sweet potato. [Online] Available: http://www.fao.org/faostat/en/\#data/QC (November 30, 2019).

Hussein, S. M., Jaswir, I., Jamal, P., \& Othman, R. (2014). Carotenoid stability and quantity of different sweet potato flesh colour over postharvest storage time. Advances in Environmental Biology, 8(3), 667-671.

IBGE (2019). Produção agrícola municipal. [Online] Available: https://sidra.ibge.gov.br/tabela/5457\#resultado (November 30, 2019).

Iese, V., Hollanda, E., Wairiu, M., Havea, R., Patolo, S., Nishi, M., Hoponoa, T., Bourke, M., Dean, A., \& Waqainabete, L. (2018). Facing food security risks: The rise and rise of the sweet potato in the Pacific Island. Global Food Security, 18, 48-56. https://doi.org/10.1016/j.gfs.2018.07.004 
Inmet (2019). Dados meteorológicos, estações automáticas. [Online] Available: http://www.inmet.gov.br/portal (June 20, 2019).

Instituto Adolfo Lutz (2005). Normas analíticas, métodos químicos e físicos para análise de alimentos. (8rd ed.). São Paulo: Instituto Adolfo Lutz. p. 371.

Khan, S. N., \& Mohsin, M. (2017). The power of emotional value: Exploring the effects of values on green product consumer choice behavior. Journal of Cleaner Production, 150, 65-74. https://doi.org/10.1016/j.jclepro.2017.02.187

Kikuchi-Uehara, E., Nakatani, J., \& Hirao, M. (2016). Analysis of factors influencing consumers' proenvironmental behavior based on life cycle thinking. Part I: Effect of environmental awareness and trust in environmental information on product choice. Journal of Cleaner Production, 117, 10-18. https://doi.org/10.1016/j.jclepro.2015.12.030

Kuzucu, M. (2019). Effects of organic fertilizer application on yield, soil organic matter and porosity on Kilis oil olive variety under arid conditions. Eurasian Journal of Forest Science, 7(1), 77-83. https://doi.org/10.31195/ejejfs.511098

Low, J., Ball, A., Magezi, S., Njoku, J., Mwanga, R., Andrade, M., Tomlins, K., Dove, R., \& Van Mourik, T. (2017). Sweet potato development and delivery in sub-saharan Africa. African Journal of Food, Agriculture, Nutrition and Development, 17(2), 11955-11972. https://doi.org/10.18697/ajfand.78.HarvestPlus07

Mantovani, J. R., Carrera, M., Moreira, J. L. A., Marques, D. J., \& Silva, A.B. (2017). Fertility properties and leafy vegetable production in soils fertilized with cattle manure. Caatinga, 30(4), 825-836. https://doi.org/10.1590/1983-21252017v30n402rc

Marques, L. F., Medeiros, D. C., Coutinho, O. L., Marques, L. F., Medeiros, C. B., \& Vale, L. S. (2010). Produção e qualidade da beterraba em função da adubação com esterco bovino. Revista Brasileira Agroecologia, 24-31. http://revistas.aba-agroecologia.org.br/index.php/rbagroecologia/article/view/7602

Mellek, J. E., Dieckow, J., Silva, V. L., Favaretto, N., Pauletti, V., Vezzani, F. M., \& Souza, J. L. M. (2010). Dairy liquid manure and no-tillage: Physical and hydraulic properties and carbon stocks in a Cambisol of Southern Brazil. Soil \& Tillage Research, 110, 69-76. https://doi.org/10.1016/j.still.2010.06.005

Moreira, F. M. S., \& Siqueira, J.O. (2006). Microbiologia e bioquímica do solo. Lavras: UFLA. p. 279.

Mueller, S., Wamser, A. F., Suzuki, A., \& Becker, W. F. (2013). Produtividade de tomate sob adubação orgânica e complementação com adubos minerais. Horticultura Brasileira, 31(1), 86-92. https://doi.org/10.1590/S0102-05362013000100014

Nicoletto, A., Galvão, A., Maucieri, C., Borin, M., \& Sambo, P. (2017). Distillery anaerobic digestion residues: A new opportunity for sweet potato fertilization. Scientia Horticulturae, 225, 38-47. https://doi.org/10.1016/j.scienta.2017.06.048 
Nsa, S. O., Okon, D. P., \& Robert, S. P. (2013). Comparative effects of chicken manure and NPK on the yield of Ipomoea batatas. Journal of Agricultural and Crop Research, 1(6), 90-93. http://www.sciencewebpublishing.net/jacr/archive/2013/December/toc.htm

Oliveira, A. P., Moura, M. F., Nogueira, D. H., Chagas, N. G., Braz, M. S. S., Oliveira, M. R. T., \& Barbosa, J. A. (2006). Produção de raízes de batata-doce em função do uso de doses de $\mathrm{N}$ aplicadas no solo e via foliar. Horticultura Brasileira, 24(3), 279-282. https://doi.org/10.1590/S0102-05362006000300002

Panja, P., Deepika., Sharma, A., \& Singh, B. (2016). Studies on physico-chemical constituents in different cultivars of sweet potato under west bengal condition. International Journal of Agriculture, Environment and Biotechnology, 9(6), 979-985. https://doi.org/10.5958/2230-732X.2016.00125.X

Rós, A. B., Narita, N., \& Hirata, A. C. S. (2014). Produtividade de batata-doce e propriedades físicas e químicas de solo em função de adubação orgânica e mineral. Semina: Ciências Agrárias, 35(1), 205-214. https://doi.org/10.5433/1679-0359.2014v35n1p205

Santos, A. F., Menezes, R. S. C., Fraga, V. S., \& Pérez-Marin, A. M. (2010b). Efeito residual da adubação orgânica sobre a produtividade de milho em sistema agroflorestal. Revista Brasileira de Engenharia Agrícola e Ambiental, 14(12), 1267-1272. https://doi.org/10.1590/S1415-43662010001200003

Santos, G. A., Silva, L. S., Canellas, L. P., \& Camargo, F. O. (2008). Fundamentos da matéria orgânica do solo: ecossistemas tropicais \& subtropicais. (2rd ed.). Porto Alegre: Metrópole. p. 636.

Santos, J. F., Brito, C. H., \& Santos, M. C. A. (2010a). Avaliação da produção de batata-doce em função de níveis de adubação orgânica. Acta Scientiarum Agronomy, 32(4), 663-666. https://doi.org/10.4025/actasciagron.v32i4.4150

SAS Institute Inc (2011). SAS/STAT 9.3 User's Guide. Cary, NC: SAS Institute Inc.

Silva, D. J., Bassoi, L. H., Rocha, M. G., Silva, A. O., \& Deon, M. D. I. (2016a). Organic and nitrogen fertilization of soil under 'Syrah' grapevine: effects on soil chemical properties and nitrate concentration. Revista Brasileira de Ciência do Solo, 40, 1-11. https://doi.org/10.1590/18069657rbcs20150073

Silva, J. A., Silva, E. M. Q., Nunes, J. C., Araujo, M. A. M., Silva, J. A., \& Souza, A. A. (2018b). Yield of sweet potato as a function of organic fertilization and intercropping with Crotalaria juncea. Agro@mbiente on-line, 12(2), 96-106. https://doi.org/10.18227/1982-8470ragro.v12i2.4664

Silva, J. O. V., Almeida, M. E., Alvim-Ferraz, M. C., \& Dias, J. M. (2018a). Integrated production of biodiesel and bioethanol from sweet potato. Renewable Energy, 124, 114-120. https://doi.org/10.1016/j.renene.2017.07.052

Silva, R. A., Souza, U. O., Santos, L. G., Melo, C. N., \& Vasconcelos, R. C. (2016b). Características agronômicas de cultivares de milho verde submetidas a doses de Ribumin ${ }^{\circledR}$. 
Revista de Ciências Agrárias, 39(3), 395-403. https://doi.org/10.19084/RCA15126

Singh, A. B., Deo, C., Kumar, S., Shrivastav, S. P., \& Sriom. (2017). Growth and yield response of sweet potato (Ipomoea batatas L.) cv. NDSP-65 to different integrated organic sources. Journal of Pharmacognosy and Phytochemistry, 6(6), 738-741. http://www.phytojournal.com/archives/

Uchôa, V. T., Noleto, D. C. A., Silva, C. R. P., \& Costa, C. L. S. (2015). Caracterização físico-química de batata-doce (Ipomoea batatas L.) comum e biofortificada. Revista Ciência Agrícola, 13(1), 59-68. https://doi.org/10.28998/rca.v13i1.2019

WRB (2014). World Reference Base for Soil Resources: A framework for international classification, correlation and communication. Food and Agriculture Organization of the United Nations. Rome: IUSS/ISRIC/FAO. [Online]. Available: http://www.fao.org/3/a-i3794en.pdf (August 08, 2020).

Yu-Kui, R., Shi-Ling, J., Fu-Suo, Z., \& Jian-Bo, S. (2009). Effects of nitrogen fertilizer input on the composition of mineral elements in corn grain. Agrociencia, 43(1), 21-27.

\section{Copyright Disclaimer}

Copyright for this article is retained by the author(s), with first publication rights granted to the journal.

This is an open-access article distributed under the terms and conditions of the Creative Commons Attribution license (http://creativecommons.org/licenses/by/4.0/). 